American Journal of Agricultural and Biological Science 1 (3): 48-57, 2006

ISSN 1557-4989

(C) 2006 Science Publications

\title{
Fat Body Cells of Gynes and Queens of Four Species of Fungus Growing Ants (Hymenoptera: Formicidae: Attini); Relationship with the Vitellogenesis
}

\author{
${ }^{1}$ G.C. Roma, ${ }^{1}$ M.I. Camargo-Mathias and ${ }^{1,2}$ O. C. Bueno \\ ${ }^{1}$ Instituto de Biociências, Departamento de Biologia, UNESP, Universidade Estadual Paulista, Avenida

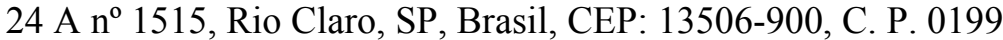 \\ ${ }^{2}$ Instituto de Biociências, Centro de Estudos de Insetos Sociais, UNESP, Universidade Estadual Paulista \\ Avenida 24 A nº 1515, Rio Claro, SP, Brasil, CEP: 13506-900, C. P. 0199
}

\begin{abstract}
The morphometric analysis of fat body cells of gynes of Cyphomyrmex rimosus and Mycetarotes parallelus and queens of Acromyrmex disciger and Atta laevigata revealed significant differences in area of parietal and perivisceral trophocytes in all studied species. This was also observed for parietal and perivisceral oenocytes. No differences, however, were observed when the areas of oenocytes of gynes are compared. The morphological study revealed that parietal and perivisceral trophocytes of gynes and queens were spherical or polygonal in shape and exhibited several vacuoles and a nucleus, often irregular in shape. These cells contained proteins, lipids and neutral polysaccharides. In gynes, however, histochemical tests for the former two components were weakly positive, as opposed to the observed in queens. Parietal and perivisceral oenocytes in all studied species were mostly spherical and exhibited vacuoles, especially in $C$. rimosus and $A$. laevigata, in which larger quantities of vacuoles were observed. The nuclei of oenocytes in gynes were spherical or oval in shape, while in queens, most were irregular. The cytoplasm of oenocytes was strongly stained for proteins and weakly stained for neutral polysaccharides in all studied species. Compared to queens, weak staining for lipids was observed in gynes.
\end{abstract}

Key words: Trophocyte, oenocyte, morphology, morphometry, histochemistry

\section{INTRODUCTION}

Ants of the Attini tribe live in symbiosis with basidiomycete fungi, which provide nutrients and enzymes to these insects. In return, ants provide a large variety of substrates to fungi and stimulate their growth $^{[1]}$.

Species comprising the Attini tribe are classified in basal genera Cyphomyrmex, Mycetophylax, Mycocepurus, Myrmicocrypta, Mycetagroicus, Apterostigma, Sericomyrmex, Mycetosoritis, Mycetarotes and Trachymyrmex and derived genera Atta and Acromyrmex. The latter are commonly known locally as "saúvas" and "quenquéns", respectively. The genus Pseudoatta comprises parasitic species ${ }^{[2]}$.

Insects exhibit a fat tissue that fills the body and does not have a shape or defined structure. It consists mainly of cells termed trophocytes, responsible for the synthesis and secretion of proteins and for the metabolism of lipids and carbohydrates ${ }^{[3,4]}$. In many cases, these cells are structurally and functionally specialized and receive specific denominations such as urocytes, chromatocytes and mycetocytes ${ }^{[5]}$.

Oenocytes represent an additional class of cells often associated to trophocytes in the fat body ${ }^{[6,7]}$, that may be involved in the synthesis of lipid and lipoprotein materials deposited in the epicuticle, forming an impermeable layer for the insect ${ }^{[8,9]}$. In addition, these cells may participate in the production of ecdysteroids that act during the molting process. Some authors suggest that oenocytes might also be involved in the elimination of toxic substances ${ }^{[3,8,10]}$.

Due to the scarce data available on the fat body of ants, more specifically on species of the Attini tribe, we conducted a comparative morphometric and histochemical analysis among trophocytes and oenocytes of gynes Cyphomyrmex rimosus Spinola and Mycetarotes parallelus Emery, as well as queens of Acromyrmex disciger Mayr and Atta laevigata Smith, with the aim to detect differences that might lead to phylogenetic implications for this tribe, in addition to assess the participation of these cells during vitellogenesis.

\section{MATERIALS AND METHODS}

The present study used the parietal and perivisceral fat body from gynes of Cyphomyrmex rimosus and Mycetarotes parallelus (monomorphic species) and queens of Acromyrmex disciger and Atta laevigata (polimorphic species), collected in the field and immediately submitted to the techniques. The

Corresponding Author: Maria Izabel Camargo Mathias, Instituto de Biociências, Departamento de Biologia, UNESP, Universidade Estadual Paulista, Avenida 24 A n ${ }^{\circ} 1515$, Rio Claro, SP, Brasil, CEP: 13506-900, C. P. 0199, Tel: +55-19-35264135, Fax:+55-19-35340009, E-mail: micm@rc.unesp.br 
individuals were anesthetized by cooling in a freezer $\left(4^{\circ} \mathrm{C}\right)$ and dissected on Petri dishes with physiological saline solution for insects $\left(\mathrm{NaCl} 7,5 \mathrm{~g} \mathrm{~L}^{-1}, \mathrm{Na}_{2} \mathrm{HPO}_{4}\right.$ $2,38 \mathrm{~g} \mathrm{~L}^{-1}, \mathrm{KH}_{2} \mathrm{PO}_{4} 2,72 \mathrm{~g} \mathrm{~L}^{-1}$ ).

Morphology: Based on the median histological sections obtained, the parietal and perivisceral fat body cells of the analyzed species were schematized with camera lucid mechanism coupled with a stereomicroscope ZEISS.

Scanning electron microscopy (SEM): The parietal and perivisceral fat body from gynes and queens was removed, fixed in Karnovsky for $24 \mathrm{hrs}$ and dehydrated in a graded $70-100 \%$ acetone series. The material was processed by Critical Point Drying, sputtered with gold and examined by PHILIPS 505 SEM.

Morphometry: The morphometric analysis of trophocytes and oenocytes was conducted using median histological sections. We utilized 05 individuals of each species. For each individual, were obtained area measurements $\left(: \mathrm{m}^{2}\right)$ of 10 parietal trophocytes and 10 perivisceral ones and 10 parietal oenocytes and 10 perivisceral ones, with a LDMB LEICA microscope with the software Leica Qwin. The statistical test applied was the Tukey $(\mathrm{p}<0,05)^{[11]}$. This test was performed in order to verify significant differences among the parietal and perivisceral trophocytes and among the parietal and perivisceral oenocytes in all species studied here. Besides this, the statistic test evaluated the significant differences among the parietal and perivisceral trophocytes among individuals at the same specie, the same procedure was applied to the oenocytes.

Histology and histochemistry: The parietal and perivisceral fat body from gynes and queens was removed and fixed in paraformaldehyde $4 \%$ and $0,9 \%$ $\mathrm{NaCl}$ in $10 \%$ phosphate buffer $(0,1 \mathrm{M}-\mathrm{pH} 7,5)$ (for routine histology and proteins detection), Bouin's solution (for acid and neutral polysaccharides detection) and calcium formol (for lipids detection). Dehydration was effected in an alcoholic series (70, 80, 90 and 95\%) at 15 min intervals. Infiltration was made with resin solution (JB-4 Polaron Instruments/Bio Rad) at $4^{\circ} \mathrm{C}$ in a dark bottle. The specimens were embedded in moulds, at $4^{\circ} \mathrm{C}$ to retard premature polymerization. The moulds with material were filled and covered with JB-4 resin and polymerization was completed at room temperature.

Sectioning was carried out $(4 \mu \mathrm{m})$ with a glass knife. Then the sections were transferred to a room temperature water bath before being placed on cleaned glass slides. After they were air dried before staining with Hematoxylin and Eosin, Bromophenol Blue (protein), PAS/Alcian Blue (acid and neutral polysaccharides) and Sudan Black B (lipids). In the PAS/Alcian Blue and Sudan Black B techniques the sections were counter-stained with Hematoxylin and Neutral Red, respectively.

\section{RESULTS AND DISCUSSION}

Scanning electron microscopy (SEM): This study reveals that the fat body of gynes of $C$. rimosus and $M$. parallelus and queens of $A$. disciger and $A$. laevigata appears as a loose clump of cells distributed around organs (perivisceral) and adjacent to the tegument (parietal) (Fig. 1).

In all species examined, parietal and perivisceral trophocytes are the main cell types observed. These cells are mostly spherical in shape, but may also be polygonal due to the compression caused by the cell arrangement, as well as the amount of cytoplasmic components (Fig. 1).

The trophocytes of gynes and queens of the examined species exhibit a slightly rough surface (Fig. 1A-H, J-K).

In queens of $A$. disciger, some trophocytes are ruptured, exposing cytoplasmic granules (Fig. 1G).

In the parietal and perivisceral fat bodies, round or oval-shaped oenocytes are found associated with and dispersed among trophocytes. Oenocytes may also exhibit a polygonal shape, as a result of the compression caused by trophocytes (Fig. 1D-F, H-K).

In the studied species, membranous expansions are observed between trophocytes and between oenocytes, surrounding and connecting these cells (Fig. 1A, C).

Several tracheoles are observed distributed among fat body cells of all species analysed (Fig. 1B-C, H-I).

Morphometry: The morphometric analysis of the fat body cells of gynes of $C$. rimosus and $M$. parallelus and of queens of $A$. disciger and $A$. laevigata reveals significant differences among the area of parietal and perivisceral trophocytes in all studied species. This is also observed for parietal and perivisceral oenocytes. No differences, however, are observed when the areas of oenocytes of gynes are compared.

The morphometric results of the fat body cells from the gynes and queens studied here were placed in the Table 1 and 2, respectively.

Morphology, histology and histochemistry: The morphological and histochemical study of the fat body cells of gynes and queens reveals that parietal and perivisceral trophocytes are characterized by the presence of proteins, lipids and neutral polysaccharides in their cytoplasm. In gynes, however, staining of proteins and lipids is weaker than that of queens. The cytoplasm of parietal and perivisceral oenocytes is strongly stained for proteins and weakly stained for neutral polysaccharides in all species, although, gynes exhibit few lipid inclusions when compared to queens. 
Am. J. Agri. \& Biol. Sci., 1 (3): 48-57, 2006

Table 1: Comparation of average area $\left(\mu \mathrm{m}^{2}\right)$ of the trophocytes of the parietal and perivisceral fat body of gynes C. rimosus and M. parallelus and queens of $A$. disciger and $A$. laevigata, through Tukey test

\begin{tabular}{|c|c|c|c|c|c|c|c|c|c|}
\hline & & \multicolumn{2}{|c|}{ C. rimosus } & \multicolumn{2}{|c|}{ M. parallelus } & \multicolumn{2}{|c|}{ A. disciger } & \multicolumn{2}{|c|}{ A. laevigata } \\
\hline & & 1 & 2 & 1 & 2 & 1 & 2 & 1 & 2 \\
\hline \multicolumn{2}{|c|}{ Average area $\left(\mu \mathrm{m}^{2}\right)$} & 1931,8 & 1745,8 & 6105,9 & 6507,8 & $10.406,2$ & $11.101,8$ & $28.583,1$ & $29.999,1$ \\
\hline \multirow{2}{*}{ C. rimosus } & 1 & - & ns & $*$ & $*$ & $*$ & $*$ & $*$ & $*$ \\
\hline & 2 & ns & - & $*$ & $*$ & $*$ & $*$ & $*$ & $*$ \\
\hline \multirow{2}{*}{ M. parallelus } & 1 & $*$ & $*$ & - & ns & $*$ & $*$ & $*$ & $*$ \\
\hline & 2 & $*$ & $*$ & $\mathrm{~ns}$ & - & $*$ & $*$ & $*$ & $*$ \\
\hline A. disciger & 2 & $*$ & $*$ & $*$ & $*$ & ns & - & $*$ & $*$ \\
\hline \multirow{2}{*}{ A. laevigata } & 1 & $*$ & $*$ & $*$ & $*$ & $*$ & $*$ & - & ns \\
\hline & 2 & $*$ & $*$ & $*$ & $*$ & $*$ & $*$ & ns & - \\
\hline
\end{tabular}

(1) parietal trophocytes

(2) perivisceral trophocytes

(*) average area with significant differences among the groups $(\mathrm{p}<0,05)$

(ns) no significant differences among the groups

Table 2: Comparation of average area $\left(\mu \mathrm{m}^{2}\right)$ of the oenocytes of the parietal and perivisceral fat body of gynes C. rimosus and M. parallelus and queens of $A$. disciger and A. laevigata, through Tukey test

\begin{tabular}{|c|c|c|c|c|c|c|c|c|c|}
\hline \multirow{3}{*}{\multicolumn{2}{|c|}{ Average area $\left(\mu \mathrm{m}^{2}\right)$}} & \multicolumn{2}{|c|}{ C. rimosus } & \multicolumn{2}{|c|}{ M. parallelus } & \multicolumn{2}{|c|}{ A. disciger } & \multicolumn{2}{|c|}{ A. laevigata } \\
\hline & & 1 & 2 & 1 & 2 & 1 & 2 & 1 & 2 \\
\hline & & 292,5 & 300,38 & 865,4 & 903,7 & $2.035,9$ & $2.133,5$ & $7.713,9$ & $8.148,7$ \\
\hline \multirow{2}{*}{ C. rimosus } & 1 & - & ns & ns & Ns & $*$ & $*$ & $*$ & $*$ \\
\hline & 2 & $\mathrm{~ns}$ & - & $\mathrm{ns}$ & Ns & $*$ & $*$ & * & * \\
\hline \multirow{2}{*}{ M. parallelus } & 1 & ns & $\mathrm{ns}$ & - & Ns & $*$ & $*$ & $*$ & $*$ \\
\hline & 2 & $\mathrm{~ns}$ & ns & ns & - & * & * & $*$ & * \\
\hline \multirow{2}{*}{ A. disciger } & 1 & $*$ & $*$ & $*$ & $*$ & - & $\mathrm{ns}$ & $*$ & * \\
\hline & 2 & $*$ & $*$ & $*$ & $*$ & ns & - & $*$ & $*$ \\
\hline \multirow{2}{*}{ A. laevigata } & 1 & $*$ & $*$ & $*$ & $*$ & $*$ & $*$ & - & $\mathrm{ns}$ \\
\hline & 2 & * & * & * & $*$ & * & $*$ & ns & - \\
\hline
\end{tabular}

(1) parietal oenocytes

(2) perivisceral oenocytes

(*) average area with significant differences among the groups $(\mathrm{p}<0,05)$

(ns) no significant differences among the groups

In all studied species, ovaries are well developed with ovarioles containing oocytes in several developmental stages.

For a better comprehension, the principal morphohistological and histochemical results of the fat body cells of gynes and queens analyzed here were summarized comparatively in the Table 3 and 4, respectively.

This study revealed that the fat body cells of gynes of $C$. rimosus and $M$. parallelus and queens of $A$. disciger and A. laevigata are distributed throughout the abdomen, around organs (perivisceral) and right underneath the tegument (parietal), corroborating the observed in the workers of these species ${ }^{[7,9]}$ and for others insects ${ }^{[3]}$.

The morphometric analysis of the fat body cells of the species examined here showed that the areas of parietal and perivisceral trophocytes are significantly different among all species. The area of trophocytes of derived species is larger than those of gynes of basal species. This might indicate that during the evolution of these insects, there was a gradual increase in the volume of these cells, probably due to a larger accumulation of substances in the trophocytes of $A$. disciger and A. laevigata, which was also accompanied by an increase in body side.
In general, trophocytes were the largest cells found in the fat body of studied species, corroborating the data obtained for queens of Atta sexdens ${ }^{[12]}$ and gynes and queens of Pachycondyla striata ${ }^{[13]}$. This might represent the physiological state of these cells, with trophocytes of gynes $C$. rimosus and $M$. parallelus, as well as those of $A$. disciger and $A$. laevigata queens producing and storing substances involved in the reproductive processes of these insects.

The morphometric results obtained for parietal and perivisceral oenocytes of gynes and queens examined in the present study revealed that these cells exhibit significantly different areas among species. However, no differences were found between oenocytes of gynes. As observed for trophocytes, the largest oenocytes were observed in derived species, which might also reflect an increase in cell volume throughout the evolution of Attini ants.

The morphometric analysis did not reveal significant differences among the areas of parietal and perivisceral trophocytes and parietal and perivisceral oenocytes in each species, confirming the data found in queens of the $A$. sexdens ants ${ }^{[2]}$ and Melipona quadrifasciata anthidioides bees ${ }^{[14]}$. These results, however, differ from those obtained in queens of 
Am. J. Agri. \& Biol. Sci., 1 (3): 48-57, 2006

Table 3: Morpho-histological and histochemical results of the trophocytes and oenocytes from gynes of Cyphomyrmex rimosus and Mycetarotes parallelus.

\begin{tabular}{|c|c|c|c|c|c|}
\hline \multirow{2}{*}{ Species } & \multirow{2}{*}{ Structures } & \multicolumn{2}{|l|}{ Trophocytes } & \multicolumn{2}{|l|}{ Oenocytes } \\
\hline & & Parietal & Perivisceral & Parietal & Perivisceral \\
\hline $\begin{array}{l}C . \\
\text { rimosus }\end{array}$ & Cytoplasm & $\begin{array}{l}\text { - several vacuoles of } \\
\text { different sizes } \\
\text { - few proteic granules } \\
(+++) \\
\text { - region among vacuoles } \\
\text { (+++) to the PAS test } \\
\text { - lipidic inclusions }(+++) \\
\text { (Figs. 2; 3A, C; 4A, C) } \\
\text { - irregular, star } \\
\text { morphology } \\
\text { - condensed chromatin } \\
\text { - presence of some } \\
\text { nucleoli } \\
\text { (Figs. 2; 3A, C; 4A) }\end{array}$ & $\begin{array}{l}\text { - several vacuoles of } \\
\text { different sizes } \\
\text { - few proteic granules } \\
(+++) \\
\text { - region among vacuoles } \\
\text { (+++) to the PAS test } \\
\text { - lipidic inclusions (+++) } \\
\text { (Figs. 2; 3B, D; 4B, E) } \\
\text { - irregular, star } \\
\text { morphology } \\
\text { - condensed chromatin } \\
\text { - presence of some } \\
\text { nucleoli } \\
\text { (Figs. 2; 3B, D; 4B) }\end{array}$ & $\begin{array}{l}\text { - acidophil } \\
\text { - }(+++) \text { to proteins } \\
\text { - }(+) \text { to neutral } \\
\text { polysaccharides } \\
\text { - lipidic inclusions }(+++) \\
\text { - presence of several } \\
\text { vacuoles of different sizes } \\
\text { (Figs. 2; 3A, C; 4A, D) } \\
\text { - regular, rounded or oval } \\
\text { - condensed chromatin } \\
\text { - presence of some } \\
\text { nucleoli } \\
\text { (Figs. 2; 3A, C; 4D) }\end{array}$ & $\begin{array}{l}\text { - acidophil } \\
-(+++) \text { to proteins } \\
-(+) \text { to neutral } \\
\text { polysaccharides } \\
\text { - lipidic inclusions }(+++) \\
\text { - presence of several } \\
\text { vacuoles of different sizes } \\
\text { (Figs. } 2 ; 3 \mathrm{~B}, \mathrm{E} ; 4 \mathrm{~B}, \mathrm{~F}) \\
\text { - regular, rounded or oval } \\
\text { - condensed chromatin } \\
\text { - presence of some } \\
\text { nucleoli } \\
\text { (Figs. } 2 ; 3 \mathrm{~B}, \mathrm{E})\end{array}$ \\
\hline \multirow[t]{2}{*}{$\begin{array}{l}\text { M. } \\
\text { parallelus }\end{array}$} & Cytoplasm & $\begin{array}{l}\text { - lipidic inclusions }(+++) \\
\text { - regions among vacuoles } \\
(+++) \text { to proteins and } \\
\text { neutral polysaccharides } \\
\text { (Figs. } 2 ; 3 \mathrm{~F}, \mathrm{H} ; 4 \mathrm{G}, \mathrm{J})\end{array}$ & $\begin{array}{l}\text { - lipidic inclusions }(+++) \\
\text { - regions among vacuoles } \\
(+++) \text { to proteins and } \\
\text { neutral polysaccharides } \\
\text { (Figs. } 2 ; 3 \mathrm{G}, \mathrm{I} ; 4 \mathrm{H}, \mathrm{L})\end{array}$ & $\begin{array}{l}\text { - acidophil } \\
\text { - }(+++) \text { to proteins } \\
\text { - }(+) \text { to the PAS test } \\
\text { - few inclusions }(+++) \text { to } \\
\text { lipids } \\
\text { - presence of some } \\
\text { vacuoles } \\
\text { (Figs. } 2 ; 3 \mathrm{~F}, \mathrm{H} ; 4 \mathrm{G}, \mathrm{K})\end{array}$ & $\begin{array}{l}\text { - acidophil } \\
-(+++) \text { to proteins } \\
\text { - }(+) \text { to the PAS test } \\
\text { - few inclusions }(+++) \text { to } \\
\text { lipids } \\
\text { - presence of some } \\
\text { vacuoles } \\
\text { (Figs. } 2 ; 3 \mathrm{G}, \mathrm{I} ; 4 \mathrm{I}, \mathrm{M})\end{array}$ \\
\hline & Nucleus & $\begin{array}{l}\text { - irregular, star form } \\
\text { - condensed chromatin } \\
\text { - presence of some } \\
\text { nucleoli } \\
\quad \text { (Figs. 2; 3F; 4G) }\end{array}$ & $\begin{array}{l}\text { - irregular, star form } \\
\text { - condensed chromatin } \\
\text { - presence of some } \\
\text { nucleoli } \\
\quad \text { (Figs. } 2 ; 3 \mathrm{G}, \mathrm{I} ; 4 \mathrm{H})\end{array}$ & $\begin{array}{l}\text { - regular, rounded } \\
\text { - condensed chromatin } \\
\text { - presence of some } \\
\text { nucleoli } \\
\quad \text { (Figs. } 2 ; 3 \mathrm{~F}, \mathrm{H} ; 4 \mathrm{G} \text { ) }\end{array}$ & $\begin{array}{l}\text { - regular, rounded } \\
\text { - condensed chromatin } \\
\text { - presence of some } \\
\text { nucleoli } \\
\quad \text { (Figs. } 2 ; 3 \mathrm{G}, \mathrm{I} ; 4 \mathrm{I})\end{array}$ \\
\hline
\end{tabular}

$(+++)$ strongly positive $\quad(+)$ weakly positive

Table 4: Morpho-histological and histochemical results of the trophocytes and oenocytes from queens of Acromyrmex disciger and Atta laevigata

\begin{tabular}{|c|c|c|c|c|c|}
\hline \multirow{2}{*}{ Species } & \multirow{2}{*}{ Structures } & \multicolumn{2}{|l|}{ Trophocytes } & \multicolumn{2}{|l|}{ Oenocytes } \\
\hline & & Parietal & Perivisceral & Parietal & Perivisceral \\
\hline $\begin{array}{l}\text { A. } \\
\text { disciger }\end{array}$ & Nucleus & $\begin{array}{l}\text { - irregular limits } \\
\text { - condensed chromatin } \\
\text { - presence of some } \\
\text { nucleoli } \\
\text { (Figs. 2; 3J, L) }\end{array}$ & $\begin{array}{l}\text { - irregular limits } \\
\text { - condensed chromatin } \\
\text { - presence of some } \\
\text { nucleoli } \\
\text { (Figs. } 2 ; 3 \mathrm{~K}, \mathrm{M})\end{array}$ & $\begin{array}{l}\text { - regular, rounded or oval } \\
\text { - condensed chromatin } \\
\text { - presence of several } \\
\text { nucleoli } \\
\text { (Figs. 2; 3J, L) }\end{array}$ & $\begin{array}{l}\text { - regular, rounded or oval } \\
\text { - condensed chromatin } \\
\text { - presence of several } \\
\text { nucleoli } \\
\text { (Figs. } 2 ; 3 \mathrm{~K}, \mathrm{M} ; 4 \mathrm{~S} \text { ) }\end{array}$ \\
\hline $\begin{array}{l}\text { A. } \\
\text { laevigata }\end{array}$ & Nucleus & $\begin{array}{l}\text { - irregular limits } \\
\text { - condensed chromatin } \\
\text { - presence of some } \\
\text { nucleoli } \\
\text { (Figs. } 2 ; 3 \mathrm{~N} \text { ) }\end{array}$ & $\begin{array}{l}\text { - irregular limits } \\
\text { - condensed chromatin } \\
\text { - presence of some } \\
\text { nucleoli } \\
\text { (Figs. } 2 ; 3 \mathrm{O})\end{array}$ & $\begin{array}{l}\text { - rounded or irregular } \\
\text { - condensed chromatin } \\
\text { - presence of some nucleoli } \\
\text { (Figs. } 2 ; 3 \mathrm{~N}, \mathrm{R} \text { ) }\end{array}$ & $\begin{array}{l}\text { - rounded or irregular } \\
\text { - condensed chromatin } \\
\text { - presence of some nucleoli } \\
\text { (Figs. 2; 3P, S) }\end{array}$ \\
\hline
\end{tabular}



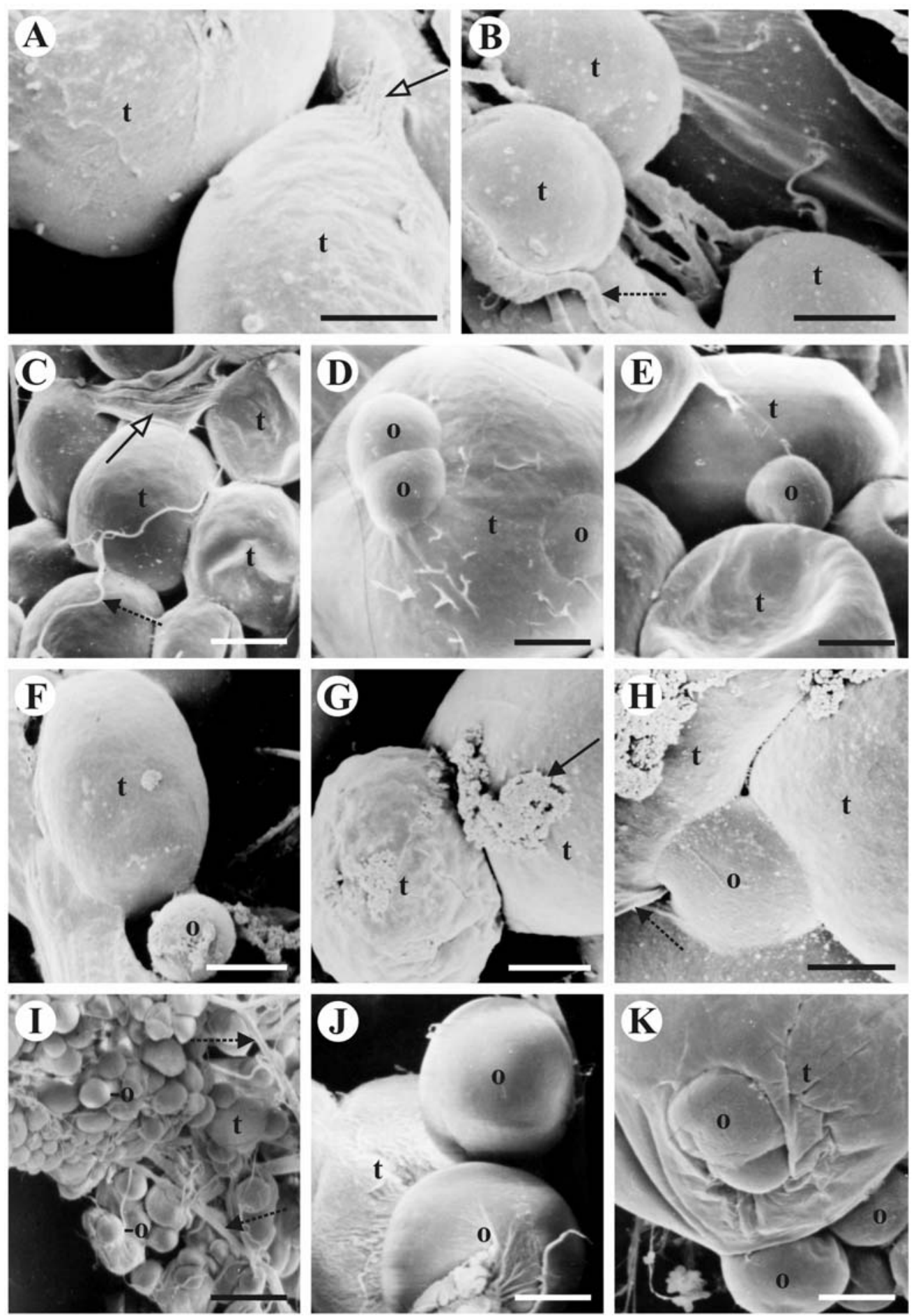

Fig. 1: Scanning Electron Microscopy (SEM) of the fat body cells from gynes of Cyphomyrmex rimosus and Mycetarotes parallelus and queens of Acromyrmex disciger and Atta laevigata, Detail of the C. rimosus parietal fat body (A) and perivisceral one (B). Parietal fat body (C, D) and perivisceral one (E) from $M$. parallelus. Detail of the A. disciger parietal fat body $(\mathbf{F})$ and perivisceral one $(\mathbf{G}, \mathbf{H})$. Parietal fat body $(\mathbf{I}, \mathbf{J})$ and perivisceral one $(\mathbf{K})$ from A. laevigata. $\mathrm{t}=$ trophocytes; $\longrightarrow=$ membranous expansion; $\longrightarrow=$ granules in the trophocyte cytoplasm; $\mathrm{o}=$ oenocytes; $\cdots \cdots=$ tracheole. Bars $\mathrm{A}, \mathrm{B}, \mathrm{G}, \mathrm{H}=10 \mu \mathrm{m}, \mathrm{C}=$ $35 \mu \mathrm{m}, \mathrm{D}, \mathrm{E}, \mathrm{F}=16 \mu \mathrm{m}, \mathrm{I}=123 \mu \mathrm{m}, \mathrm{J}=25 \mu \mathrm{m}, \mathrm{K}=40 \mu \mathrm{m}$ 
Am. J. Agri. \& Biol. Sci., 1 (3): 48-57, 2006

\section{Cyphomyrmex rimosus}
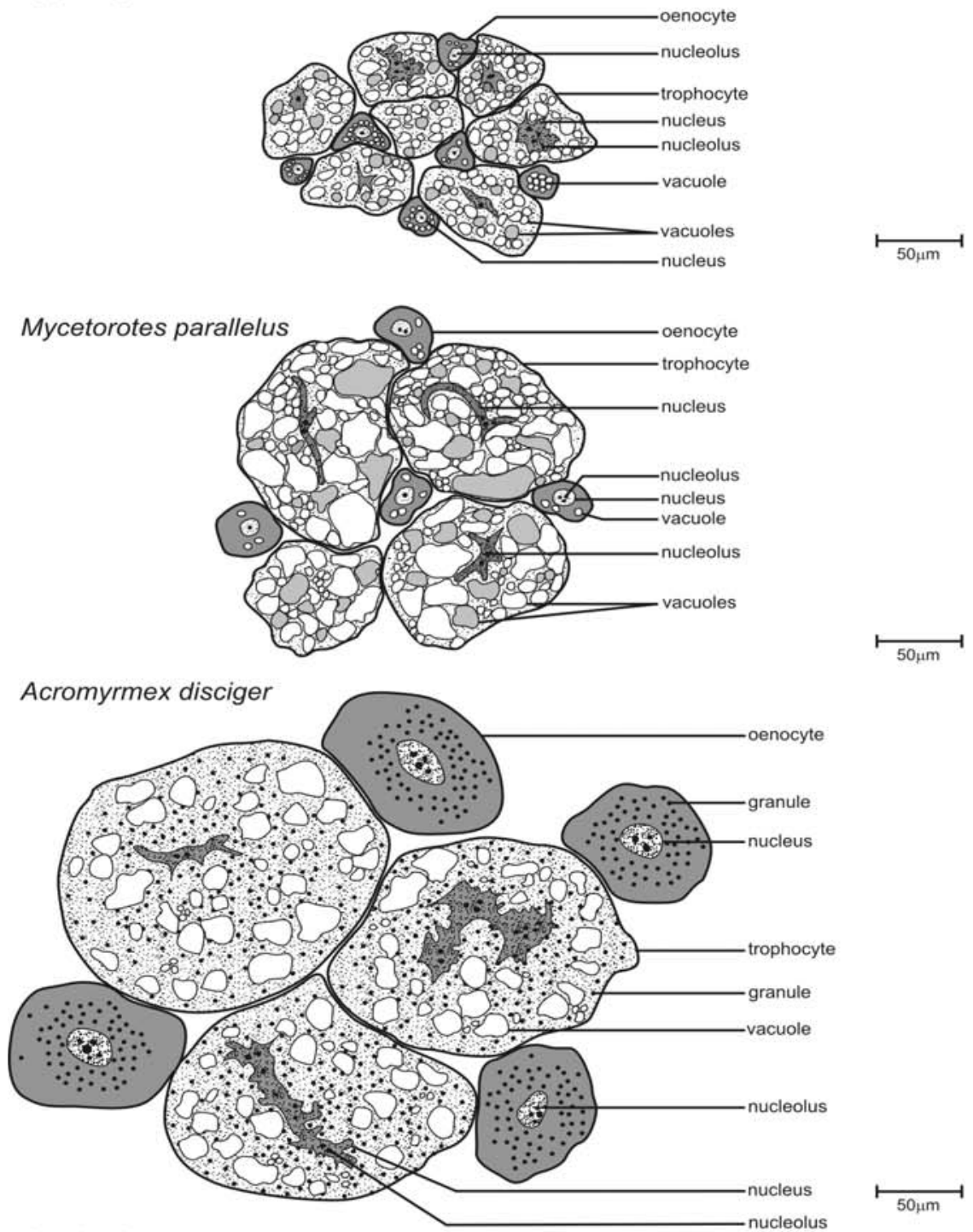

Atta laevigata

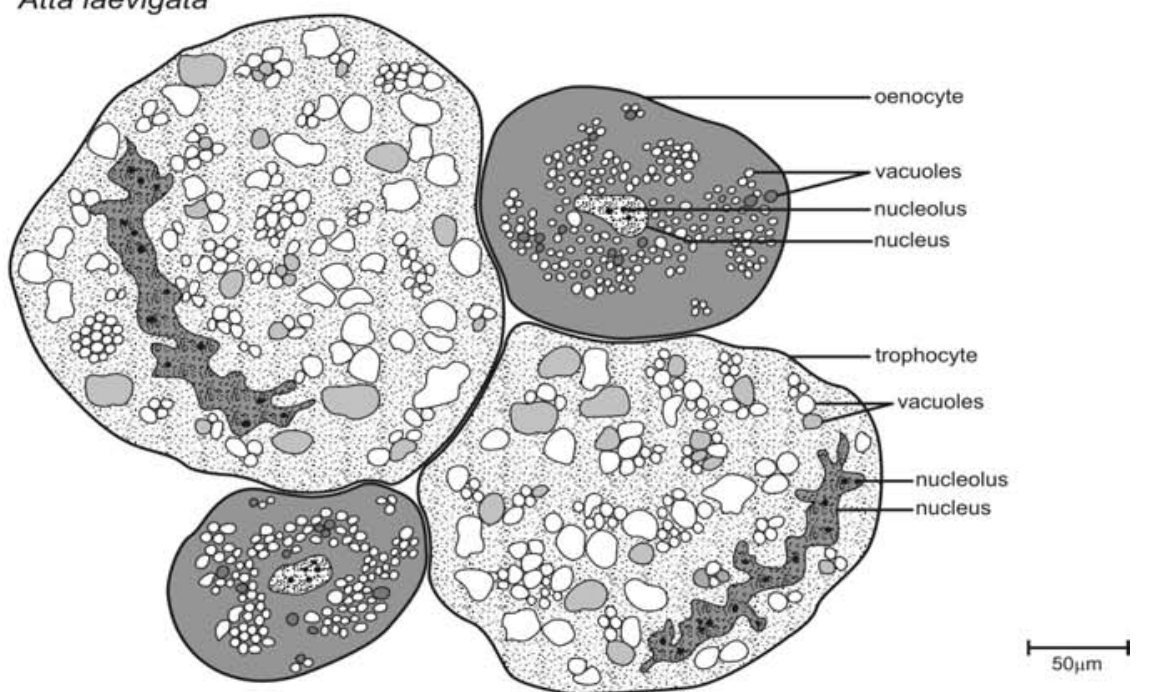

Fig. 2: Schematic representation of the fat body cells from gynes of Cyphomyrmex rimosus and Mycetarotes parallelus (basal species) and queens of Acromyrmex disciger and Atta laevigata (derived species) 

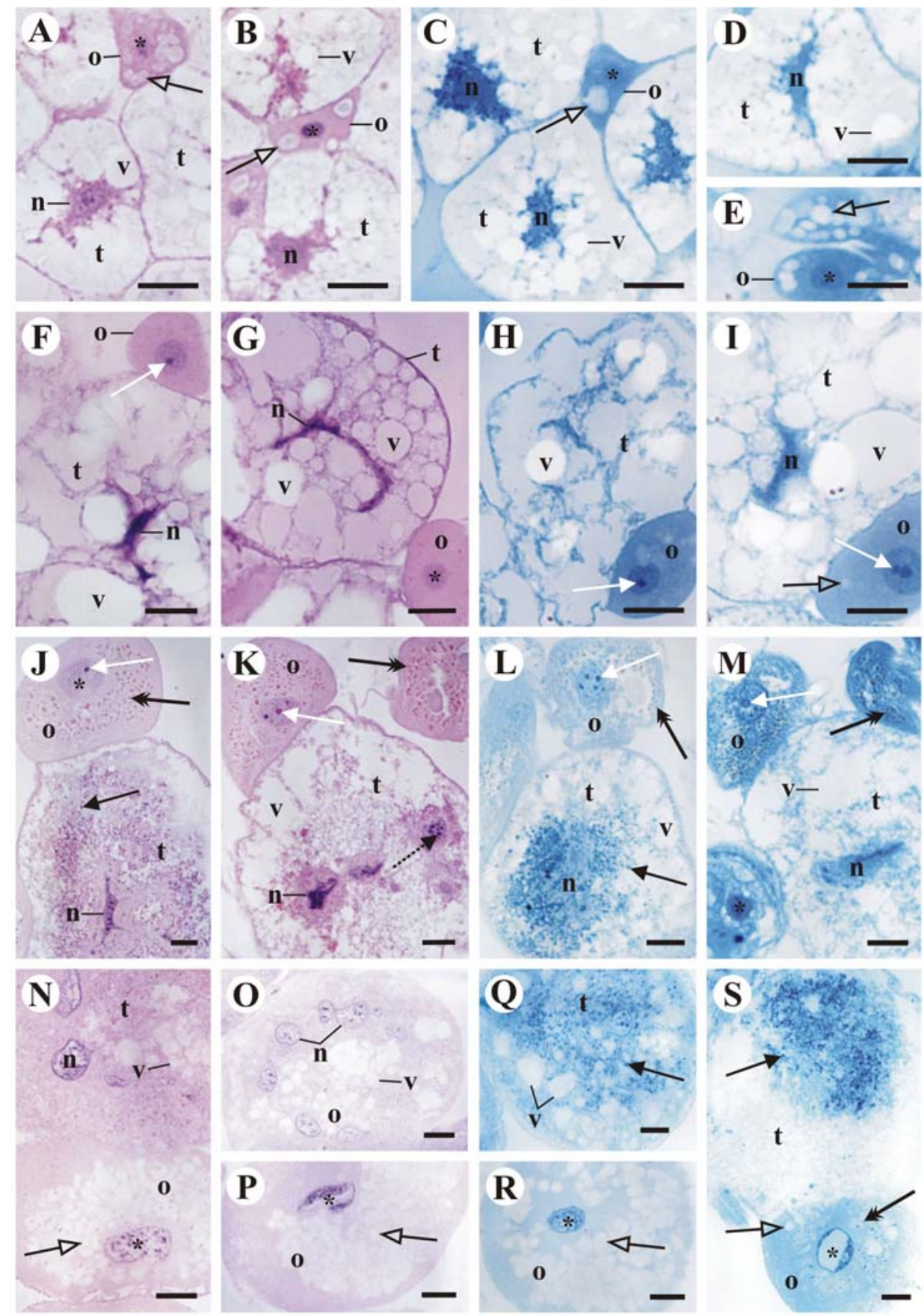

Fig. 3: Histological sections of the fat body cells from gynes of Cyphomyrmex rimosus and Mycetarotes parallelus and queens of Acromyrmex disciger and Atta laevigata. Detail of C. rimosus parietal fat body (A) and perivisceral one (B), stained by Hematoxylin and Eosin. Parietal fat body (C) and perivisceral one (D, E) from C. rimosus, stained by Bromophenol Blue. Parietal fat body (F) and perivisceral one (G) from $M$. parallelus, stained by Hematoxylin and Eosin. Detail of M. parallelus parietal fat body $(\mathrm{H})$ and perivisceral one (I), stained by Bromophenol Blue. Parietal fat body (J) and perivisceral one (K) from A. disciger, stained by Hematoxylin and Eosin. Detail of $A$. disciger parietal fat body (L) and perivisceral one (M), stained by Bromophenol Blue. Parietal fat body $(\mathrm{N})$ and perivisceral one $(\mathrm{O}, \mathrm{P})$ from A. laevigata, stained by Hematoxylin and Eosin. Detail of A. laevigata parietal fat body $(\mathrm{Q}, \mathrm{R})$ and perivisceral one $(\mathrm{S})$, stained by Bromophenol Blue. $\mathrm{t}=$ trophocytes; $\mathrm{n}=$ trophocyte nucleus; $\cdots-\cdots=$ trophocyte nucleolus; $\mathrm{v}=$ vacuole; $\longrightarrow$ granules in the trophocyte cytoplasm; o = oenocytes; $*=$ oenocyte nucleus; white arrow $=$ oenocyte nucleolus; $\longrightarrow=$ vacuoles in the oenocyte cytoplasm; $\longrightarrow=$ granules in the oenocyte cytoplasm. Bars $=20 \mu \mathrm{m}$ 


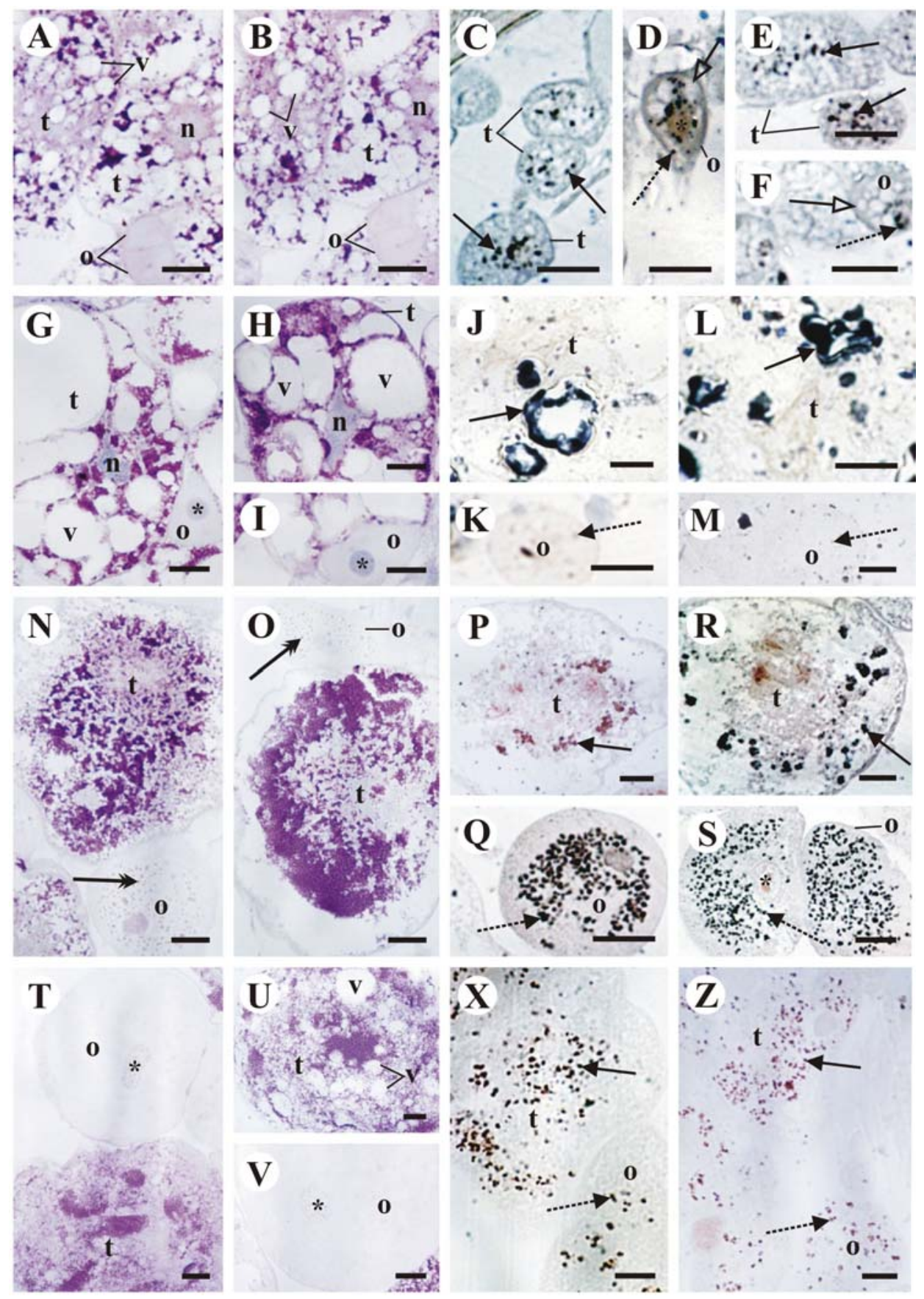

Fig. 4: Histological sections of the fat body cells from gynes of Cyphomyrmex rimosus and Mycetarotes parallelus and queens of Acromyrmex disciger and Atta laevigata. Detail of C. rimosus parietal fat body (A) and perivisceral one (B), stained by PAS/Alcian Blue. Parietal fat body (C, D) and perivisceral one (E, F) from C. rimosus, stained by Sudan Black B. Parietal fat body $(\mathrm{G})$ and perivisceral one (H, I) from M. parallelus, stained by PAS/Alcian Blue. Detail of M. parallelus parietal fat body (J, K) and perivisceral one (L, M), stained by Sudan Black B. Parietal fat body $(\mathrm{N})$ and perivisceral one $(\mathrm{O})$ from A. disciger, stained by PAS/Alcian Blue. Detail of $A$. disciger parietal fat body $(\mathrm{P}, \mathrm{Q})$ and perivisceral one $(\mathrm{R}, \mathrm{S})$, stained by Sudan Black B. Parietal fat body (T) and perivisceral one (U, V) from A. laevigata, stained by PAS/Alcian Blue. Detail of $A$. laevigata parietal fat body $(\mathrm{X})$ and perivisceral one $(\mathrm{Z})$, stained by Sudan Black B. $\mathrm{t}=$ trophocytes; $\mathrm{n}=$ trophocyte nucleus; $\mathrm{v}=$ vacuole; $\longrightarrow=$ lipidic inclusions in the trophocyte cytoplasm; $\mathrm{o}=$ oenocyte; $*=$ oenocyte nucleus; $\longrightarrow=$ vacuoles in the oenocyte cytoplasm; $\longrightarrow$ granules in the oenocyte cytoplasm; $\cdots-\cdots=$ lipidic inclusions in the oenocyte cytoplasm. Bars $=20 \mu \mathrm{m}$ 
Apis mellifera $^{[15]}$, which have two distinct populations of oenocytes thus showing in basal ant species as well as derived ants here examined, an absence of functional compartmentalization among parietal and perivisceral cells.

The morpho-histochemical results showed a close association among parietal and perivisceral trophocytes and oenocytes, although without fusion of membranes, which was also reported for gynes and queens of the $P$. striata ants ${ }^{[16]}$. Thin membranous expansions, however, were observed between trophocytes and oenocytes in all studied species, as also observed in queens of $P$. striata $^{[13]}$ and workers of the Attini tribe (unpublished data). These expansions might maintain the cohesion among fat body cells and provide support to this slack tissue, corroborating the data found in A. mellifera ${ }^{[17]}$.

The cytoplasm of parietal and perivisceral trophocytes of all four species exhibited many vacuoles evenly distributed throughout the cell cytoplasm. Previous studies on ants workers ${ }^{[7,9]}$ have reported fewer and smaller vacuoles, suggesting that reproductive castes produce and store larger amounts of substances in fat body cells, due to their larger demands for proteins, carbohydrates and lipids that will constitute the yolk ${ }^{[3,18]}$. These data confirm those obtained for queens of the $A$. sexdens ${ }^{[12]}$ and gynes and queens of $P$. striata ${ }^{[16]}$.

Trophocytes of the species examined in this study adopted a polygonal morphology resulted from the compression of the large number of vacuoles, as observed in queen ${ }^{[12]}$ and gynes ${ }^{[16]}$ of other ant species. Similarly, these vacuoles present in the cytoplasm of these cells also caused their nuclei to become irregular in shape.

The nuclei of parietal and perivisceral trophocytes and oenocytes of the study species exhibited several nucleoli, indicating an intense protein synthesis in these cells.

Weaker staining for proteins was observed in trophocytes of gynes of $C$. rimosus and M. parallelus than in queens of $A$. disciger and $A$. laevigata, corroborating the observed for the same castes of the bee $M$. quadrifasciata anthidioides ${ }^{[19]}$. According this study, the difference in the synthesis and storage of proteins might be due to the fact that in gynes, oocytes are probably in previtellogenic phase, in which substances have not yet accumulated in oocytes, such as vitellogenic proteins, that are synthesized in trophocytes to constitute the yolk ${ }^{[8,20,21]}$. In the species here examined, however, the results suggest that perivisceral trophocytes, located near the ovaries, might already be synthesizing and storing proteins, even in gynes, since their ovaries and those of queens are developed. Similarly, also found proteins in trophocytes of gynes of the ant Camponotus festinatus ${ }^{[22]}$.
In this study, the oenocytes of the all four ant species contained proteins in the cytoplasm, confirming the observed in gynes and queens of $P$. striat ${ }^{[16]}$. The role of these proteins in oenocytes of insects remain uncertain, however, the presence of many oenocytes located around the ovaries of these studied species, as well as in the ant Pachycondyla villos ${ }^{[23]}$, might indicate that they in fact participate in the final stages of oogenesis, especially in the formation of the chorion, the protective membrane externally surrounding the eggs of insects.

Regarding polysaccharides, we observed the presence of neutral polysaccharides in parietal and perivisceral trophocytes of the studied species, as also observed in queens of the ants $A$. sexdens ${ }^{[12]}$ and gynes of P. striata ${ }^{[16]}$.

The polysaccharides observed in the trophocytes of the ants here studied could play a role in several metabolic processes, mainly during reproduction, when the demand for energy increases considerably, especially during oogenesis ${ }^{[8]}$. Alternatively, polysaccharides might be involved in supplying the necessary energy for wing muscles used during mating.

Oenocytes of studied species were weakly stained with PAS, except for a few stained granules in queens of $A$. disciger, unlike the observed in gynes of $P$. striata $^{[16]}$, which have a complete absence of polysaccharides in these cells. Our data suggest that polysaccharides might be produced and immediately utilized in chemical reactions in these cells, such as catabolism or biosynthesis of several molecules ${ }^{[24]}$.

Lipids inclusions were detected in trophocytes of gynes of C. rimosus and M. parallelus and queens of $A$. disciger and $A$. laevigata. These elements are characterized as the main reserve material found in trophocytes of insects ${ }^{[3]}$, which may be used as components of the yolk of oocytes.

In this study, oenocytes of gynes exhibited lipid inclusions; in queens of $A$. disciger and A. laevigata, inclusions were more abundant. The presence of lipids in oenocytes has been also reported for other insects ${ }^{[3]}$. As mentioned previously, these cells might play a role in the formation of the external membrane of the egg of insects consisted of lipids and proteins ${ }^{[23,25]}$.

In general, the present results suggest that in gynes and queens of these ants' species, trophocytes and oenocytes probably play the same roles in the storage of proteins, neutral polysaccharides and lipids, that might be directed involved in the vitellogenesis.

Despite larger quantities of proteins and lipids observed in fat body cells of derived species, as well as their morphological differences, these might not be representative of basal and derived species, indicating that during the evolution of these insects, there were no changes in the morphology and chemical composition of these cells contents. 


\section{ACKNOWLEDGMENTS}

This work was financed by the FAPESP (Fundação de Amparo à Pesquisa do Estado de São Paulo), Grant $\mathrm{n}^{\circ}$ 04/01768-0. We are grateful to CEIS (Centro de Estudos de Insetos Sociais) for the insects supply and to Antonio Teruyoshi Yabuki, Cristiane Marcia Miléo, Gerson Mello Souza, Mônica Iamonte, Rogerio Sueshiro Hatore and Rogilene Aparecida Prado for the technical support.

\section{REFERENCES}

1. Silva, A., M. Bacci Jr, C. Gomes de Siqueira, O.C. Bueno, F.C. Pagnocca and M.J.A. Hebling, 2003. Survival of Atta sexdens workers on different food sources. J. Insect Physiol., 49: 307-313.

2. Bolton, B., 2003. Synopsis and classification of Formicidae. Memoirs of the American Entomological Institute, pp: 370.

3. Chapman, R.F., 1998. The Insect: Structure and Function. University Press, pp: 770.

4. Locke, M., 1984. The Structure and Development of the Vacuolar System in the Fat Body of Insects. In: Insect Ultrastructure (Eds. R.C. King and H. Akai), pp: 151-197. Plenum Press, New York.

5. Paes de Oliveira, V.T. and C. Cruz-Landim, 2003a. Morphology and function of insect fat body cells: A review. Biociências, 11: 195-205.

6. Cruz-Landim, C., 1985. Histological and cytological studies on the fat body of the queen honeybee abdomen during the active oviposition phase. Rev. Bras. Biol., 45: 221-232.

7. Roma, G.C., O.C. Bueno and M.I. CamargoMathias, 2005. Comparative study of the fat body in some genera of the Attini tribe (Hymenoptera: Formicidae). Sociobiology, 45: 449-462.

8. Keeley, L.L., 1985. Physiology and Biochemistry of the Fat Body. In: Comprehensive Insect Physiology, Biochemistry and Pharmacology (Eds. G.A. Kerkut and L.I. Gilbert), Pergamon Press, Oxford, 3: 211-248.

9. Roma, G.C., M.I. Camargo-Mathias and O.C. Bueno, 2006. Fat body in some genera of leafcutting ants (Hymenoptera: Formicidae). Proteins, lipids and polysaccharides detection. Micron, 37: 234-242.

10. Ruvolo, M.C.C. and C. Cruz-Landim, 1995b. Quantitative analyses of the relative volume occupied by oenocytes in the parietal fat body and wax epithelium development in Apis mellifera workers. Rev. Bras. Entomol., 39: 111-114.

11. Siegel, S. and N.J. Castellan Jr, 1988. Nonparametric Statistics for the Behavioral Sciences. McGraw-Hill, pp: 399.

12. Ignatti, A.C., 2001. Histoquímica e citoquímica ultra-estrutural do corpo gorduroso de rainhas de formigas Atta sexdens (L., 1758) (Hymenoptera: Formicidae). Tese (Doutorado em Biologia Celular e Molecular) - Instituto de Biociências, Universidade Estadual Paulista, Rio Claro, SP, Brasil.
13. Thiele, E. and M.I. Camargo-Mathias, 2003. Morphology, ultramorphology and morphometry of the fat body of virgin females and queens of the ants Pachycondyla striata (Hymenoptera: Formicidae). Sociobiology, 42: 243-254.

14. Paes de Oliveira, V.T. and C. Cruz-Landim, $2003 \mathrm{~b}$. Size of fat body trophocytes and the ovarian development in workers and queens of Melipona quadrifasciata anthidioides. Sociobiology, 41: 701-709.

15. Ruvolo, M.C.C. and C. Cruz-Landim, 1993. Morphologic and morphometric aspects of oenocytes of Apis mellifera queens and workers in different phases of life. Mem Inst Oswaldo Cruz, 88: 387-395.

16. Thiele, E., 2001. Estudo morfo-histológico, morfométrico, histoquímico e ultra-estrutural do corpo gorduroso de fêmeas aladas e rainhas de formigas Pachycondyla striata (Hymenoptera: Ponerinae). Dissertação (Mestrado em Biologia Celular e Molecular) - Instituto de Biociências, Universidade Estadual Paulista, Rio Claro, SP, Brasil.

17. Cruz-Landim, C., 1976. Connective tissue of Apis mellifera: an ultrastructural study. Insectes Soc., 23: 263-276.

18. Gullan, P.J. and P.S. Cranston, 2000. The Insects: An Outline of Entomology. Blackwell Science, pp: 470.

19. Paes de Oliveira, V.T., 2002. Ultra-estrutura do corpo gorduroso e desenvolvimento do ovário em rainhas e operárias de Melipona quadrifasciata anthidioides Lep. Dissertação (Mestrado em Biologia Celular e Molecular) - Instituto de Biociências, Universidade Estadual Paulista, Rio Claro, SP, Brasil.

20. Büning, J., 1994. The Insect Ovary. Ultrastructure, Previtellogenic Growth and Evolution. Chapman and Hall, pp: 400.

21. Hartfelder, K. and W. Engels, 1998. Social insect polymorphism: hormonal regulation of plasticity in development and reproduction in the honeybee. Curr. Top. Dev. Biol., 40: 45-77.

22. Wheeler, D.E. and T. Martinez, 1995. Storage proteins in ants (Hymenoptera: Formicidae). Comp. Biochem. Physiol., 112B: 15-19.

23. Camargo-Mathias, M.I. and F.H. Caetano, 1996. Ultrastructural cytochemistry of oenocytes of Pachycondyla villosa ants (Hymenoptera: Ponerinae). Acta Microsc., 5A: 6000-6003.

24. Candy, D.J. and B.A. Kilby, 1975. Insect Biochemistry and Function. Chapman and Hall, pp: 314.

25. Ruvolo, M.C.C. and C. Cruz-Landim, 1995a. Oenocytes of honey bee queen (Hymenoptera: Apidae): Relationships with ovarian development. Rev. Bras. Entomol., 39: 297-301. 